\title{
PREVALENCE OF EATING DISORDER ATTITUDES AMONG MEN AND WOMEN WITH EXERCISE DEPENDENCE SYMPTOMS:
}

\section{A NON-ATHLETE POPULATION STUDY'}

\author{
MS. ELAINE FERNANDA DA SILVA \\ Instituto de Ciências Biológicas, Universidade Federal de Goiás \\ (Goiânia - Goiás - Brasil) \\ E-mail: elainesudbio@hotmail.com
}

\section{GRAD. ALIANE RAMALHO DA SILVA \\ Instituto de Ciências Biológicas, Universidade \\ Federal de Goiás (Goiânia - Goiás - Brasil) \\ E-mail: ali_ane@hotmail.com}

\author{
ESP. AMARILIS DIAS DA SILVA \\ Centro Universitário São Camilo (Campus Ipiranga) \\ (Ipiranga - São Paulo - Brasil) \\ E-mail:amarilisdias@terra.com.br
}

\section{DR. GUSTAVO RODRIGUES PEDRINO}

Instituto de Ciências Biológicas, Universidade

Federal de Goiás (Goiânia - Goiás - Brasil)

E-mail: gpedrino@gmail.com

\section{DR. DANIEL ALVES ROSA}

Instituto de Ciências Biológicas, Universidade

Federal de Goiás (Goiânia - Goiás - Brasil)

E-mail: danielr@icb.ufg.br

\begin{abstract}
The present study sought to describe the prevalence of Secondary Exercise Dependence (SCED, i.e. eating disorders attitudes along with exercise dependence symptoms) may differ between men and women in a broader exercising population. In this study, 174 regularly exerciser,

I. We would like to thank all the volunteers who contributed to this study. The Conselho Nacional de Desenvolvimento Científico e Tecnológico (CNPq) by granting undergraduate research scholarship (PIBIC).
\end{abstract}


aged I 8 -62 years old, who were invited to respond the Exercise Dependence Scale (EDS) and the Eating Attitudes Test (EAT-26). There were more women than men with ScED. However, only men in the sample presented exercise dependence symptoms without eating disorders attitudes. Eating disorders may or may not exist in those who are exercise dependent in the broad exercising population, although there is a higher prevalence of ScED in women than men.

KEYWORDS: Dependence; Exercise; Feeding Behavior; Questionnaires.

\section{INTRODUCTION}

Although the regular involvement in physical exercise results in physical and psychological benefits (PATE et al., 1995; SCULLY et al., 1998; WOLFF et al., $20 \mathrm{II}$ ) based on the recommendations of specialized agencies, a large portion of the population does not exercise in a manner that is sufficient to achieve the benefits (MATSUDO et al., 2002; CUNHA et al., 2008). However, although it seems paradoxical, individuals who engage in the regular practice of physical exercises in an irrepressible way (i.e., they are excessively concerned with physical exercise routines) present mood changes when they are unable to exercise (withdrawal symptoms). In addition, these exercisers also report occupational or social problems as a result of their commitment to exercise. The most popular theory about the excessive exercising states that this phenomenon is a specific form of dependency (SACHS; PARGMAN, 1979; GRIFFITHS, 1997; ADAMS, 2009). The term "exercise dependence" refers to a practice of exercises as a compulsive behavior. DeCoverley Veale's ( 1987) definition of exercise dependence has gained the most recognition. This author recommended a set of standards for diagnosing dependence, based on the DSM-IV criteria for substance dependence, which is characterized by a maladaptive pattern of exercising that leads to clinically significant impairment or distress. According to DeCoverley Veale, the following other characteristics are associated with exercise dependence: I) the individual continues the practice of exercises despite illness, injury and any other medical contraindication or when the practice of physical exercise negatively affects their personal relationships with a mate, family, friends or work colleagues; 2) the individual diets for weight loss as a way to improve performance.

There has been a great deal of attention from exercise researchers over the last three decades on the connection between the compulsion to exercise and eating disorders (BAMBER; COCKERILL; CARROLL, 2000; BAMBER; COCKERILL; CARROLL, 2003; ADAMS, 2009; BRATLAND-SANDA et al., 20 I0; STILES-SHIELDS et al., 20 I I). There is considerable clinical evidence that many patients with eating disorders also present with exercise hyperactivity. Studies have shown that of the approximately $80 \%$ of women with anorexia nervosa and bulimia nervosa, half of 
them excessively exercised during the acute phase of their illness (DAVIS, 1997; DAVIS, et al., 1997; SHROFF et al., 2006). In addition, a large portion of these patients reported involvement in competitive sports and/or regular physical activity programs before they developed an eating disorder. These data suggest that physical activity can have a central effect in the development of eating disorders (DAVIS et al., 1995; MEYER et al., 20 I I). In addition, several studies have demonstrated a high prevalence of eating disorders in athletes in sports that require high levels of physical fitness, such as marathon running, triathlons, rowing, boxing and rhythmic gymnastics (WARREN; STANTON; BLESSING, I990; THIEL; GOTTFRIED; HESSE, 1993; KLOCK; SOUSA, 1995; BLAYDON; LINDNER, 2002; PATEL et al., 2003).

The exercise dependence symptoms associated with eating disorders are characterized as "secondary" exercise dependence, i.e., a dependency related to another compulsive behavior. However, there is evidence that not all individuals with exercise dependence symptoms have an eating disorder. In contrast, the data suggest that "primary" exercise dependence describes the dependence on exercise in the absence of an eating disorder (DECOVERLEY VEALE, 1987). The main issue is not the existence of primary exercise dependence, even though this syndrome is not recognized by the World Health Organization (ORGANIZAÇÃO MUNDIAL DA SAÚDE (OMS), 1993) but whether there is a significant distinction between individuals who present primary or secondary exercise dependence. Many researchers believe that both types of exercise dependence are a common pattern of compulsive behavior (ADAMS; KIRKBY, 1998). However, few studies have investigated the prevalence of eating disorders in the wider exercising population (i.e., non-athletes) or compared eating disorders with symptoms of exercise dependence with an analysis of the characteristics that are central to this association. Thus, our study aimed to analyze the prevalence of eating disorder attitudes and their relationship with exercise dependence symptoms among men and women who exercised regularly.

METHOD

\section{PARTICIPANTS}

The sample was comprised of 105 men and 69 women, between 18 to 62 years old, who exercised regularly and filled out fully the both questionnaires described below. They were contacted directly by the researchers at public parks, jogging area or outside at gym in the city of Goiânia-GO, Brazil. After being informed of the 
study objectives and methodology, the subjects signed an informed consent form for participation in accordance with the rules of the Committee of Ethics on Research of the Federal University of Goiás, who approved the research protocol ( 156/2008).

\section{MATERIALS}

\section{QUESTIONNAIRES}

Exercise Dependence Scale (EDS) (ROSA; MELLO; SOUZA-FORMIGONI, 2003) - This questionnaire focuses on the "negative" psychological aspects of exercise dependence on a scale of I 4 items, with each item scored as $0=$ absence or I = presence. High EDS scores are associated with high exercise dependence symptoms. The EDS has already been translated and validated from the original version of the Negative Addiction Scale (HAILEY; BAILEY, 1982) for the Portuguese that is spoken in Brazil by Rosa, Mello and Souza-Formigoni (2003). Questions such as the type, weekly frequency, duration and time of involvement in the physical activity were added to the top of this questionnaire for the purposes of the present study.

Eating Attitudes Test summarized (EAT-26) (GARNER; OLIMSTED; GARFINKEL, 1982) - The Brazilian version of the EAT-26 was used (NUNES, et al., 2005); this test assesses the potential risk of developing behavior and attitudes that are typical of patients with eating disorders. The EAT-26 is a self-reported, internationally recognized instrument that is employed to evaluate and identify abnormal eating patterns. It is also useful in monitoring the evolution of clinical or sub-clinical cases of eating disorders. The scores obtained for each item of the EAT-26 were computed and summed for each study subject. If the total score was higher than 21 , the EAT-26 was considered positive (EAT-26+) and suggested the presence of abnormal eating attitudes or the risk for developing an eating disorder.

\section{DESIGN AND PROCEDURE}

According to the questionnaire scores, subjects were divided into four distinct groups: I) Secondary Exercise Dependence (ScED) - these subjects had scores greater than or equal to 21 on the EAT-26 $\left(\right.$ EAT-26 ${ }^{+}$) and received an EDS score equal to or above $75^{\text {th }}$ percentile; 2) Primary Exercise Dependence (PrED) these subjects scored less than 21 on the EAT-26 but scored equal to or above the $75^{\text {th }}$ percentile on the EDS; 3) Eating Attitudes Risk (EAR) - these subjects were EAT-26+ but had EDS scores lower than $75^{\text {th }}$ percentile; and 4) Neutral Group (NG) - these subjects scored less than 21 on the EAT-26 and were low scoring on the EDS (less than $75^{\text {th }}$ percentile). We compared the number of men and women in each group and analyzed what characteristics that could explain the prevalence rates among the gender. 
We initially applied the Kolmogorov-Smirnov test to determine the curve of normality. Student's t-test was used to compare the means obtained for men and women within each group. To compare the number of men and women in each group, a Pearson Chi-Square test was applied. The statistical significance level established for all tests was 5\%. The analyses were performed using the Statistica software, StatSoft, Inc. Tulsa, OK, USA.

\section{RESULTS}

Although no significant differences were found between men and women on total EDS score $(5.7 \pm 2.4$, vs $5.4 \pm 2.3)$, the women shows a higher score on the EAT-26 than men (women, $24 \pm 10.5$ vs men, $17 \pm 10.3, p<0.001$ ). The proportion of men and women in each group is shown in Table I. Note that of the 39 individuals in the ScED group, there were more women than men. This was also true in the EAR group. However, all 26 individuals in the PrED were men. There were no significant differences in the mean age of men and women (TABLE 2).

Table I. Proportion of men and women in each subject group

\begin{tabular}{lllll}
\hline Group & Men & Women & \\
& $N=105$ & $\mathrm{~N}=69$ & $c^{2} \mid g=1$ & $p$ \\
\hline \hline ScED (39) & $16(41 \%)$ & $23(59 \%)$ & 7,84 & $\mathrm{p}=0,0 \mathrm{I}$ \\
PrED (26) & $26(100 \%)$ & $00(0 \%)$ & - & - \\
EAR (35) & $14(40 \%)$ & $21(60 \%)$ & 7,57 & $\mathrm{p}=0,0 \mathrm{I}$ \\
NG (74) & $49(66 \%)$ & $25(34 \%)$ & 1,85 & ns \\
\hline \hline
\end{tabular}

ScED = Secondary Exercise Dependence; PrED = Primary Exercise Dependence; EAR = Eating Attitudes Risk; NG $=$ Neutral Group.

Table 2. Ages of men and women in each group

\begin{tabular}{lll}
\hline Group & MEN & WOMEN \\
\cline { 2 - 3 } ScED & MEAN (SD) & MEAN (SD) \\
\cline { 2 - 3 } PrED & $33(9.4)$ & $33(12.1)$ \\
EAR & $27(11.1)$ & - \\
NG & $33(10.2)$ & $30(10.5)$ \\
\hline
\end{tabular}


To analyze the factors that were associated with the higher prevalence of women in the ScED group, a categorical variables test was created. We used running/ walking or gym/other for physical activity type; up to $60 \mathrm{~min}$ or more than $60 \mathrm{~min}$ for duration of session; 2-4 days/week or 5-7 days/week for weekly frequency and up to 5 or more than 5 years for length of regular physical activity. In the category "other" physical activity, the following types of physical activity were found at high frequencies: bodybuilding (13\%), gymnastics (12\%) and martial arts, swimming, etc. (7\%); of the remainder of the sample, $30 \%$ were composed by runners and 38\% who did walking as exercise. As shown in Table 3, there were no significant differences in the proportion of men and women in the ScED group who engaged in each categorical variable.

Table 3. Type, duration of sessions, weekly frequency and length of regular physical activity in men and women in the Secondary Exercise Dependence group (ScED)

\begin{tabular}{|c|c|c|c|c|}
\hline \multirow[b]{2}{*}{ FACTOR OF PHYSICAL ACTIVITY } & \multicolumn{2}{|l|}{ ScED (39) } & \multirow[b]{2}{*}{$c^{2} g l=I$} & \multirow[b]{2}{*}{$p$} \\
\hline & Men (\%) & Women (\%) & & \\
\hline \multicolumn{5}{|l|}{ TYPE } \\
\hline walking/jogging (25) & $12(48)$ & $13(52)$ & & \\
\hline gym/other (14) & $04(29)$ & $10(7 \mid)$ & 1,400 & 0,23 \\
\hline \multicolumn{5}{|l|}{ SESSION DURATION } \\
\hline up to 60 minutes (13) & $04(31)$ & $09(69)$ & & \\
\hline$>60$ minutes $(26)$ & $12(46)$ & I4 (54) & 0,847 & 0,35 \\
\hline \multicolumn{5}{|l|}{ WEEKLY FREQUENCY } \\
\hline 2-4 days/wk (I5) & $5(33)$ & $10(67)$ & & \\
\hline 5-7 days/wk (24) & I | (46) & $13(54)$ & 0,596 & 0,44 \\
\hline \multicolumn{5}{|l|}{ LENGTH } \\
\hline Up to 5 yr. $(2 \mathrm{I})$ & $07(33)$ & $14(67)$ & & \\
\hline$>5$ yr. (I8) & $09(50)$ & $09(50)$ & 1,112 & 0,29 \\
\hline
\end{tabular}

\section{DISCUSSION}

This study showed a higher prevalence of women with symptoms of "secondary" exercise dependence. That is, women who regularly exercised had a higher association between eating disorder attitudes and exercise dependence symptoms than did men. In addition, distinct characteristics such as age, length of exercise engagement, duration of session and weekly frequency of physical activity were not associated 
with this higher correlation in women. In contrast, only men presented a kind of "primary" exercise dependence, i.e. they scored high on exercise dependence symptoms but low on eating disorder attitudes.

According to Assunção, Cordás and Araújo (2002), 90\% of eating disorders occur in females. In the current study, we used the EAT-26, which is used for tracking individuals who are susceptible to developing anorexia and bulimia nervosa. This questionnaire indicates the presence of abnormal eating behavior, which suggests a risk of underlying psychopathology.

Nunes et al. (2005) states that scores above 21 points on the EAT-26 are suggestive of more risk for developing an eating disorder (i.e., EAT-26+). In our sample, we noted that only $25 \%$ of all women interviewed scored less than 21 on the EAT-26, whereas the vast majority was EAT-26+. In contrast, $75 \%$ of men scored less than 21 on the EAT-26 (data not presented).

According to Garner and Friedman (1995), there are many individuals who have an abnormal thoughts, feelings, or behaviors in relation to eating but do not present one or more criteria for an eating disorder diagnosis. In addition, the sub-clinical cases of eating disorders occur in mainly in women. The present study reported a significant association between the EAT-26+ and high exercise dependence symptoms only in women. Indeed, other studies corroborate our results. Through a diagnostic speech analysis interview of exercise dependence in women, Bamber et al. (2003) reported that all women with exercise dependence symptoms in their study also were diagnosed with an eating disorder according to DSM-IV criteria. Moreover, Bratland-Sanda et al. (20 I I) recently observed an association between scores of exercise dependence in adult female patients with symptoms of eating disorders. Thus, this phenomenon cannot be attributed only by chance.

If the risk of eating disorder attitudes is more prevalent in women than men, one could assume that secondary exercise dependence would also be more common in women than men. However, in the current study, we demonstrate that $41 \%$ of the subjects in the ScED group were men, suggesting that secondary exercise dependence also occurs in men. How, therefore, can we explain this phenomenon within the paradigm of eating disorders in men? Some authors suggest that the practice of excessive jogging could be an analogue of eating disorders in men (YATES; LEEHEY; SHISSLAK, I 983; BAYES; MADDEN, 20 I I); the essential motivation for the excessive exercise focused primarily on the concern about weight and body image (HAUSENBLAS; FALLON, 2002). On the other hand, this same motivation also exists in male bodybuilders, who use diet and excessive workouts to control weight (PIERCE; MORRIS, 1998; MURRAY et al., 20 I2). In fact, there are reports in the literature of a subgroup of bodybuilders with body image disorders (POPE; KATZ; 
HUDSON, 1993). Such disorders, which the authors termed "reverse anorexia", are characterized by an individual's pathological fear of becoming very fragile and skinny, even when they are very strong.

On the other hand, the present study demonstrated the presence of exercise dependence symptoms without EAT-26+ in men, suggesting that primary exercise dependence does exist in males. This finding leads to the hypothesis that exercise dependence as a phenomenon "per se" could exist mainly in males. However, the study developed by Blaydon and Lindner (2002) has demonstrated the presence of primary exercise dependence in female triathletes. The most plausible explanation for the absence of women in the PrED group in the present study is the fact that all participants belonged to the general population (i.e., they were interviewed in public places) and were not members of a specific sporting group.

Whereas exercise can trigger a behavior similar to a dependency isolated from other factors, what are the mechanisms that would lead a person to become dependent on physical exercise? The main hypotheses proposed by studies about exercise addiction are those related to both physiological and psychological factors associated with the practice of physical exercises (for a review see Hamer; Karageorghis (2007).

Rosa et al. (2004) used the same exercise dependence scale and measured the alteration in mood state after an acute exercise test of three distinct groups: sedentary subjects, exercisers with low levels of exercise dependence and exercisers with high levels of exercise dependence. In his study, it was found that only exercisers with high levels of addiction were the most prone to changes mood states induced by an acute exercise test, indicating that for these subjects, exercise produced a negative reinforcement that contributed to the development of exercise dependence. However, Modolo et al. (20 I I) showed that there were no differences in negative mood states between male and female amateur athletes with exercise-dependence symptoms. This finding suggests a distinction between athletes and the wider exercising population in terms of the development of exercise dependence symptoms.

Some limitations of the current study should be noted. First, the EDS did not specify a cutoff point for classification of exercise dependence. Therefore, it is not possible to determine if a subject actually was or was not exercise dependent. The classification of subjects into different groups was based on the assumption that high EDS scores indicate the most symptoms that associated with dependence, while low EDS scores indicate the absence of exercise dependence. Although the EAT- $26^{+}$is accepted in the literature as an indication of the risk for developing eating disorders, other diagnostic methods could suggest other clinical eating psychopathology indicators. However, the subjects in the present study were interviewed in public places, than use of instruments to measure physical parameters correctly was not possible. 
Our novel data indicate that in a broad exercising population, eating disorders may or may not exist in those who are exercise dependent. However, further studies should be conducted with other instruments and/or other diagnostic methods to evaluate both eating disorders and exercise dependence to determine the profile of these two phenomena among men and women. In addition, studies are also needed to explore the short and long term consequences of the association between eating disorders and exercise dependence to understand the underlying mechanisms of this type of behavioral addiction.

Prevalência de transtornos alimentares entre homens e mulheres com sintomas de dependência de exercícios: um estudo na população de não atletas

RESUMO: O presente estudo buscou descrever a prevalência da Dependência de Exercícios Secundário (DESc, ou seja, atitudes alimentares de risco associadas com sintomas de dependência de exercícios) entre homens e mulheres em uma população não-atleta. Neste trabalho, 174 praticantes regulares de exercícios fisicos, entre 18 e 62 anos, quando abordados responderam à Escala de Dependência de Exercícios (EDE) e ao Eating Attitudes Test (EAT-26). Houve mais mulheres do que homens com DESC. Contudo, somente os homens apresentaram sintomas de dependência de exercícios com ausência de atitudes alimentares de risco. Os transtornos alimentares podem ou não ocorrer entre não-atletas dependentes de exercícios fisicos, embora haja uma maior prevalência de DESc entre as mulheres.

PALAVRAS CHAVE: Dependência; exercício; comportamento alimentar; questionários.

Prevalencia de los trastornos alimentarios entre hombres y mujeres con síntomas de dependencia de ejercicios: estudio de la población no deportista RESUMEN: El estudio tiene como objetivo describir la prevalencia de la Dependencia de Ejercicio Secundaria (DESC, a saber riesgo de trastornos alimentarios asociado con los síntomas de dependencia de ejercicios) entre hombres y mujeres en una población no atleta. En este trabajo, 174 practicantes de ejercicios físicos regulares, entre 18 y 62 años, cuando abordados respondieron a la Escala de Dependencia del Ejercicio (EDE) y Eating Attitudes Test (EAT-26). Hubo más mujeres que hombres con DESc. Todavía, sólo los hombres mostraron síntomas de dependencia de ejercicios desasociado de los riesgos de trastorno alimentarios. Trastornos alimentarios pueden existir entre los practicantes de ejercicios no deportistas, aunque hay una mayor prevalencia de mujeres con DESC.

PALABRAS CLAVE: Dependencia; ejercicio; comportamiento alimentario; cuestionarios. 


\section{REFERENCE}

ADAMS, J.; KIRKBY, R. J. Exercise dependence: a review of its manifestation, theory and measurement. Research Sport in Medicine, Philadelphia, v. 8, n. 3, p. 265-276, july 1998.

ADAMS, J. Understanding exercise dependence. Journal of Contemporary Psychotherapy, New York, v. 39, n. 4, p. 231-240, may/june 2009.

ASSUNÇÃO, S. S. M.; CORDÁS, T. A.; ARAÚJO, L. A. S. B. Atividade física e transtornos alimentares. Revista de Psiquiatria Clínica, São Paulo, v. I9, p. 4-13, 2002.

BAMBER, D. et al. "It's exercise or nothing": a qualitative analysis of exercise dependence. British Journal of Sports Medicine, Loughborough, v. 34, n. 6, p. 423-430, dec. 2000.

BAMBER, D. J. et al. Diagnostic criteria for exercise dependence in women. British Journal of Sports Medicine, Loughborough, v. 37, n. 5, p. 393-400, oct. 2003.

BAYES, A.; MADDEN, S. Early onset eating disorders in male adolescents: a series of 10 inpatients. Australasian Psychiatry, Carlton, v. 19, n. 6, p. 526-530, dec. 2011.

BLAYDON, M. J.; LINDNER, K. J. Eating disorders and exercise dependence in triathletes. Eating Disorders, New York, v. I0, n. I, p. 49-60, nov./dec. 2002.

BRATLAND-SANDA, S. et al. Physical activity and exercise dependence during inpatient treatment of longstanding eating disorders: an exploratory study of excessive and non-excessive exercisers. International Journal of Eating Disorders, New York, v. 43, n. 3, p. 266-273, apr. 2010.

BRATLAND-SANDA, S. et al. Exercise dependence score in patients with longstanding eating disorders and controls: the importance of affect regulation and physical activity intensity. European Eating Disorders Review, Chichester, v. 19, n. 3, p.249-255, may/june 201 I.

CUNHA, I. C. et al. Fatores associados à prática de atividade física na população adulta de Goiânia: monitoramento por meio de entrevistas telefônicas. Revista Brasileira de Epidemiologia, São Paulo, v. I I, n. 3, p. I-9, set. 2008.

DAVIS, C. et al. Obsessive compulsiveness and physical activity in anorexia nervosa and high level exercising. Journal of Psychosomatic Research, London, v. 39, n. 8, p. 967-976, nov. 1995.

DAVIS, C. Eating disorders and hyperactivity: a psychobiological perspective. Canadian Journal of Psychiatry, Ottawa, v. 42, n. 2, p. 168-175, mar. 1997.

DAVIS, C. et al. The prevalence of high-level exercise en the eating disorders: etiological implications. Comprehensive Psychiatry, Philadelphia, v. 38, n. 6, p. 321-336. nov./dec. 1997.

DECOVERLEY VEALE, M. C. Exercise dependence. British Journal of Addicition, Oxfordshire, v. 82, n. 7, p. 735-740, july 1987.

GARNER, D. M; FRIEDMAN, L. L. Distúrbios da alimentação. In: DATTILIO, F. M.; FREEMAN, A. Estratégias cognitivo-comportamentais para intervenções em crise. Campinas: Editorial Psy, 1995. 
GARNER, D. M; OLIMSTED, M. P; GARFINKEL, P. E. The eating attitudes test: psychometric features and clinical correlates. Psychological Medicine, London, v. I2, n. 4, p. 87I-878, nov. 1982.

GRIFFITHS, M. Exercise addiction: a case study. Addiction Research and Theory, Amsterdam, v. 5, n. 2, p. |6|-168. 1997.

HAILEY, B. J; BAILEY, L. A. Negative addiction in runners: a quantitative approach. Journal of Sport Behaviour, Mobile, v. 5, n. 3, p. 150-154, sept. 1982.

HAMER, M; KARAGEORGHIS, C. I. Psychobiological mechanisms of exercise dependence. Sports Medicine, Auckland, v. 37, n. 6, p. 477-484. 2007.

HAUSENBLAS, J. A.; FALLON, E. A. Relationship among body image, exercise behavior, and exercise dependence symptoms. International Journal of Eating Disorders, New York, v. 32, n. 2, p. 179-185, sept. 2002.

KLOCK, S. C.; SOUSA, M. J. Eating disorder characteristic and psychiatric symptomatology of eumenorrheic and amenorrheic runners. International Journal of Eating Disorders, New York, v. 17, n. 2, p.161-166, mar. 1995.

MATSUDO, S. M. et al. Nível de atividade física da população do Estado de São Paulo: análise de acordo com o gênero, idade, nível socioeconômico, distribuição geográfica e de conhecimento. Revista Brasileira Ciência e Movimento, Taguatinga, v. I0, n. 4, p. 4I -50, out. 2002.

MEYER, C. Compulsive exercise and eating disorders. European Eating Disorders Review, Chichester, v. 19, n. 3, p. 174-189, may/june 201।.

MODOLO, V. B. et al. Negative addiction to exercise: are there diferences between genders? Clinics, São Paulo, v. 66, n. 2, p. 255-260, oct. 201 I.

MURRAY, S. B. et al. A comparison of eating, exercise, shape, and weight related symptomatology in males with muscle dysmorphia and anorexia nervosa. Body Image, Amsterdam, v. 9, n. 2, p. 193-200, mar. 2012.

NUNES, M. A. et al. The validity and 4-year test-retest reliability of the Brazilian version of the Eating Attitudes Test-26. Brazilian Journal of Medical Biological Research, Ribeirão Preto, v. 38, n. I I, p. 1655-1662, oct. 2005.

ORGANIZAÇÃO MUNDIAL DA SAÚDE (OMS). Classificação de Transtornos Mentais e de Comportamento da CID-10. Porto Alegre: Artes Médicas, 1993.

PATEL, D. R. et al. Eating disorders in adolescent athletes. Journal Adolescence Research, Newbury Park, v. I 8, n. 3, p. 280-296, may 2003.

PATE, R. R. et al. Physical activity and public health: a recommendation from the centers for disease control and prevention and the American College of Sports Medicine. JAMA, Chicago, v. 273, n. 5, p. 402-407, feb. 1995.

PIERCE, E. F;; MORRIS, J. T. Exercise dependence among competitive power lifters. Perceptual and Motor Skills, Missoula, v. 86, n. 3, p. 1097-2008, june 1998. 
POPE, H. G.; KATZ, D. L; HUDSON, J. I. Anorexia nervosa and <<reverse anorexia >> among 08 male bodybuilders. Comprehensive Psychiatry, Philadelphia, v. 34, n. 6, p. 406409, nov./dec. 1993.

ROSA, D. A. et al. Mood changes after maximal exercise testing in subjects with symptoms of exercise dependence. Perceptual and Motor Skills, Missoula, v. 99, n. I, p. 34 I-353, aug. 2004.

ROSA, D. A.; MELLO, M. T.; SOUZA-FORMIGONI, M. L. O. Dependência da prática de exercícios físicos: estudos com maratonistas brasileiros. Revista Brasileira de Medicina do Esporte, São Paulo, v. 9, n. I, p. 9- |4, jan./fev. 2003.

SACHS, M.; PARGMAN D. Running addiction: a depth interview examination. Journal of Sport Behaviour, Mobile, v. 2, n. 3, p. I43-155, may 1979.

SCULLY, D. et al. Physical exercise and psychological well-being: a critical review. British Journal of Sports Medicine, London, v. 32, n. 2, p. I I I-120, june 1998.

$\mathrm{SHROFF}, \mathrm{H}$. et al. Features associated with excessive exercise in women with eating disorders. International Journal of Eating Disorders, New York, v. 39, n. 6, p. 454-46I, sept. 2006.

STILES-SHIELDS, E. C. et al. Driven exercise among treatment-seeking youth with eating disorders. Eating Behaviors, New York, v. 12, n. 4, p. 328-331, sept. 2011.

THIEL, A.; GOTTFRIED, H.; HESSE, F. W. Subclinical eating disorders in male athletes. Acta Psychiatrica Scandinavica, Malden, v. 88, n. 4, p. 259-255, oct. 1993.

WARREN, B. J.; STANTON, A. L.; BLESSING, D. L. Disordered eating patterns in competitive female athletes. International Journal of Eating Disorders, New York, v. 9, n. 5 , p. 565-569, sept. 1990.

WOLFF, E. et al. Exercise and physical activity in mental disorders. European Archives of Psychiatry and Clinical Neuroscience, Berlin, v. 26I, n. 2, p. I86-191, sept. 201 I.

YATES, A; LEEHEY, K.; SHISSLAK, C. M. Running: an analogue of anorexia? New England Journal of Medicine, Boston, v. 309, n. I, p. 48-58, july 1983.

Recebido em: 02 maio 2012

Aprovado em: 28 ago. 2012

Endereço para correspondência:

Daniel Alves Rosa

Estrada do Campus, s/n

Universidade Federal de Goiás, ICB 2/ Sala II 3

Goiânia-GO

CEP: 7400 I-970 